\title{
Evaluation of PT Adaro Indonesia's Corporate Social Responsibility (CSR) Program Policy, South Kalimantan, Indonesia
}

\author{
Reno Affrian, Agus Sukrisyanto, Bambang Kusbandrijo \\ Faculty of Social and Political, University of 17 Augustus 1945 Surabaya, Kota SBY, Indonesia
}

Email address:

renoaffrian@gmail.com (R. Affrian), agussukris@untag-sby.ac.id (A. Sukrisyanto),b_kusbandrijo@untag-sby.ac.id (B. Kusbandrijo)

\section{To cite this article:}

Reno Affrian, Agus Sukrisyanto, Bambang Kusbandrijo. Evaluation of PT Adaro Indonesia's Corporate Social Responsibility (CSR) Program Policy, South Kalimantan, Indonesia. Journal of Public Policy and Administration. Vol. 5, No. 3, 2021, pp. 90-96.

doi: $10.11648 /$ j.jppa.20210503.14

Received: August 11, 2021; Accepted: August 26, 2021; Published: August 31, 2021

\begin{abstract}
PT Adaro Indonesia is a mining company that conducts coal exploration and mining activities with the 3rd largest production in the world, one of the mining locations is located in Balangan Regency, South Kalimantan, Indonesia, Based on data released by the Central Statistics Agency for South Kalimantan in 2016 - 2019 economic growth balance in Balangan Regency. is the lowest economic growth among other regencies/cities, Bank Indonesia (BI) South Kalimantan region in 2019 the mining sector is still the prima donna of economic growth in the province of South Kalimantan, especially in Balangan Regency, if you look closely this shows that there are problems when viewed from one of the indicators of success community empowerment, theoretically it is stated that empowerment should not create dependence, but must be able to encourage the creation of creativity and community independence. This study aims to (1) analyze the policies of PT Adaro Indonesia's corporate social responsibility (CSR) program in Community Empowerment in Balangan Regency, (2) analyze the impact of PT Adaro Indonesia's corporate social responsibility (CSR) program on Community Empowerment in Balangan Regency and (3) Finding the right program policy evaluation model in community empowerment. The research method used in this study is a descriptive method with a qualitative approach. Determination of informants purposively (purposeful), the analysis technique used is data reduction, data display, verification. The results show that (1) PT Adaro Indonesia's corporate social responsibility (CSR) policy in empowering the people of Balangan Regency has not been implemented optimally, (2) the impact of PT Adaro Indonesia's CSR program has not fully provided a positive impact for the government and the people of Balangan Regency., (3) the program policy evaluation model that researchers offer starts from 1. Management Management, 2. Defined programs, 3. Target groups, 4. Implementation and 5. Impact. The advice given is that the authorities need to redesign the management of PT Adaro Indonesia's CSR funds.
\end{abstract}

Keywords: Evaluation of Program Policies, Corporate Social Responsibility (CSR), Community Empowerment

\section{Background}

Law of the Republic of Indonesia Number 40 of 2007 concerning Limited Liability Companies Article 72 states that companies carrying out business activities in the field and or activities of natural resources are obliged to carry out social and environmental responsibilities.

PT Adaro Indonesia is a mining company that carries out exploration and coal mining activities with the 3rd largest production in the world (CNBC Indonesia). PT Adaro Indonesia's operational office is located in Tabalong Regency, South Kalimantan Province. While the mining locations are located in Balangan Regency and Tabalong Regency, South Kalimantan province.

PT Adaro Indonesia implements a corporate social responsibility (CSR) program around the mining site as a form of responsibility for the impact of the company's operations. According to Suharto Corporate social responsibility is a business operation with a commitment not only to increase financial profits, but also to build socio-economic friends in a holistic, institutional and sustainable manner. [16]" Aras, Crowther and Frynas explains that a program can be recognized as a company's responsibility for the impact of their business on society and the environment [7]". 
Based on data released by the Central Statistics Agency (BPS) of South Kalimantan in 2016 - 2019, Balangan Regency's economic growth balance is the lowest among other regencies/cities in South Kalimantan, with an economic growth of 2.53 percent, Balangan Regency ranks 13th out of 13 regencies/cities. City [3]". Based on data from Bank Indonesia (BI) for the South Kalimantan Region in 2019 the mining sector is still the prima donna of economic growth in the province of South Kalimantan, especially in Balangan Regency [4]".

Based on these data, it shows that there are problems when viewed fromone indicator of the success of community empowerment, theoretically it is stated that Empowerment should not create dependence, but must be able to encourage the creation of creativity and independence of the community so that they have the ability to be independent, self-reliant, self-funded and self-managed for the implementation of activities in order to achieve the goals, hopes and desires of the target community; Community empowerment by itself is centered on the economic sector, because the main goal is to make the community independent [10].

Based on the description of the data presented in both the theoretical aspect and the empirical phenomenon, it is deemed necessary to evaluate PT Adaro Indonesia's corporate social responsibility (CSR) program in empowering the people of Balangan Regency, analyzing the impact of PT Adaro Indonesia's corporate social responsibility program in empowering the people of Balangan Regency., as well as finding the right evaluation model in community empowerment program policies.

\section{Literature Review}

Prastowo and Huda Responsibility of organization for the impacts of its decisions and activities on society and the environment, through transparent and ethical behavior that contributes to sustainable development, including health and the welfare of society; takes into account the expectations of stakeholders; is in compliance with applicable law and consistent with international norms of behavior; and is integrated throughout the organization and practiced in its relationship. [12]". Wibisono, CSR is a continuing commitment by the business community to act ethically and contribute to the economic development of the local community or the wider community, along with improving the standard of living of workers and their families. [17]'. Kotler \& Nance, defines CSR as a corporate commitment to improve the welfare of the surrounding community through business practice policies and the contribution of corporate resources. From this understanding, it appears that CSR is a social responsibility of the company in relation to internal and external parties. [9]".

Anderson in Winarno in general, policy evaluation can be said as an activity that involves the estimation or assessment of policies that include the substance, implementation and impact of the implementation of the policy. [18]". Laster \& Stwart (2000) in Agustino Policy evaluation seeks to assess the policy consequences shown by its impacts and assess the success or failure of a policy based on the criteria and standards made [2]". William N Dunn Evaluation can be eauated with appraisal, rating anda assessment. [6]". J. L Fitzptrick in Islamy Evaluation as the indefication, clarification and application of defensible criteria to determine an evaluation object's value (worth or merit) in relation to those criteria, [8]".

\subsection{Policy Evaluation Model}

Lester and Steward, Jr. categorize policy evaluation into four types. The types or models proposed are as follows [2]:

1. Process Evaluation. Evaluation related to the policy implementation process.

2. Impact Evaluation. Evaluation related to the results and or the effect of policy implementation.

3. Policy Evaluation. Evaluation to test the suitability of the policy results with the objectives to be achieved.

4. Meta Evaluation. evaluation of various existing policy implementations, to find certain similarities.

James Anderson divides the evaluation (implementation) of public policies into tasks. The first type is public policy evaluation which is understood as a functional activity that is always attached to every public policy, the second evaluation focuses on policy work, the third is a systematic evaluation to measure policy or measure achievement compared to the set targets [11].

Jones in wahab suggests that basically policy evaluation is carried out for 3 purposes, namely [1]".

1. Political evaluation (the evaluation is political). Conducted to see if the program provides benefits to the country. Could this be construed to open up opportunities for re-election, to gain media support, or to solicit campaign donations.

2. Organizational evaluation (organizational evaluation). This evaluation is carried out to obtain answers about whether the policies or programs that have been implemented have given rise to support for implementing agencies. Whether the benefits to these agencies exceed the costs incurred. Whether the policy is carried out, leads to further expansion for these agencies.

3. Substantive evaluation (evaluation that is substantive or real). That is an evaluation carried out to see whether the policies or programs that have been carried out have achieved the goals that have been set both legally and in detail the policies to be achieved next, as well as what impact the policy or program has on the problem in question.

\subsection{Keley Models}

Research Policy evaluation is one of the methods used to evaluate policies using evaluation principles and methods to assess the content, implementation and impact of a policy. 


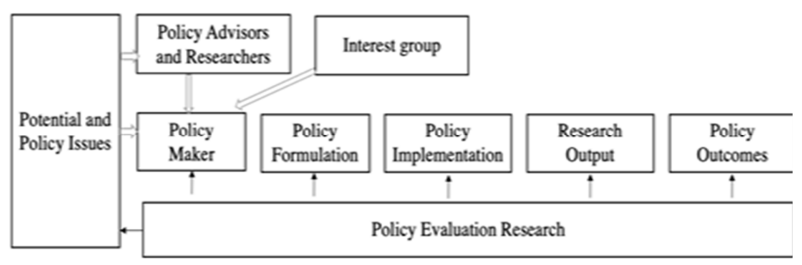

Figure 1. Scope of evaluation research in the policy prosess.

Keley as quoted by Sugiyono policy evaluation is a component in the policy process. In the policy process, policy makers will formulate policies based on their own thoughts, targets from advisors or researchers, and include community leaders, parties and the government. [14]"

\subsubsection{Potential and Policy Issues}

Policy research can conduct evaluation research on policy potentials and problems, which are used as material for policy making. Evaluation can be done based on documents and opinions of meeting participants and group discussions in making a policy. The possible results are potential and relevant problems or irrelevant to the policy formulation.

\subsubsection{Policy Maker Profile}

This research was conducted to determine the profile of policy makers, interest groups and or pressure groups. Profiles can be seen from educational background, occupation, religion of residence, participation in political and social organizations, competency qualifications, and interests in a policy.

\subsubsection{Policy Formulation}

This research is related to the policy formulation process, how long it takes for a policy to be made, the people involved in policy formulation, ideas raised during discussions in policy formulation, policy objectives, public testing, socialization and scope of policy content, clarity of content. policy formulation, the purpose of research in this section is to find out the background of the policy formulation, and how well the policy formulation is understood and useful for the people who are subject to the policy.

\subsubsection{Policy Implementation}

Policy implementation research is the same as policy implementation process research. The main purpose of research on this aspect is to find out how far the programs that have been formulated in the policy can be implemented. The scope of research in policy implementation is related to policy implementation strategies, resources for policy implementers, qualifications and competencies of policy implementers, monitoring system for policy implementers.

\subsubsection{Research output}

Research on products resulting from a policy. The research in this section aims to find out how far the objectives or policy outputs are achieved. The outputs assessed are the quality, quantity, benefits, efficiency and effectiveness of the resources and costs used to produce the output compared to the established standards.

\subsubsection{Policy Outcomes}

Research on policy outcomes or impacts is research related to the positive or negative consequences of achieving outputs. If the output is achieved or not achieved what are the positive and negative consequences.

\section{Research Methods}

This study uses a qualitative research approach that is informative by using descriptive methods. Qualitative descriptive research is one type of research method that seeks to describe and interpret objects according to what they are. [15] The data processed in this study are primary data and secondary data, primary data is data that is directly obtained in the field through in-depth interviews and observations made by researchers, secondary data is data that has been officially published obtained from the media, documentation and archives from related institutions., interview data collection methods, observation and documentation, data analysis techniques, reduction, display and conclusion drawing/verification [13]".

\section{Research Result}

The implementation of this research is using Keley policy evaluation theory as a research guidence. On this basis, the aspects evaluated relate to. 1. Potential and Policy Problems, 2. Policy Profile, 3. Policy Formulation, 4. Implementation, 5 Outputs, and 6. Outcomes.

\subsection{Potential and Policy Issues}

The formulation of PT Adaro Indonesia's CSR program in empowering the people of Balangan Regency has not fully used the potential approach and policy issues, it can be seen from the Corporate Social Responsibility Team (TJSP) which was formed through the Balangan Regent's Decree that has not fully implemented participatory approach, mapping, investigation of community needs in the formulation of a program policy, so that the concept of corporate social responsibility has not been fully implemented in accordance with the CSR mission itself.

\subsection{Policy Profile}

Based on the decision of the Regent of Balangan Number: $188.45 / 328 /$ Kum of 2021 concerning the Establishment of the Corporate Social Responsibility Work Team in 2021, it is known that the elements of the team formulating PT Adaro Indonesia's CSR program are filled by officials of the State Civil Apparatus (ASN) based on echelon ranks in the regional government. The Regent and Deputy Regent as Trustees, the Regional Secretary as Team Leader for the Head of the Economic and Development Division as Team Secretary, and several elements of the Head of Service as members of the Corporate Social Responsibility Team who are entrusted with formulating PT Adaro Indonesia's CSR program. If you look closely, the team has not involved various elements, such as 
NGOs, academics, community leaders, village heads, and elements of other interest groups. Ideally policy makers need input from various sectors, which later is expected to provide complete, accurate and up to date information, according to the needs of the community, so that the participation of interest groups is needed in the formulation of a program, involving interest groups will increase community participation in the implementation, monitoring and evaluation of the programs that have been formulated. Moreover, the concept of empowerment is an ideal concept involving various sectors.

\subsection{Policy Formulation}

The following is the mechanism flow for the formulation of PT Adaro Indonesia's CSR program.

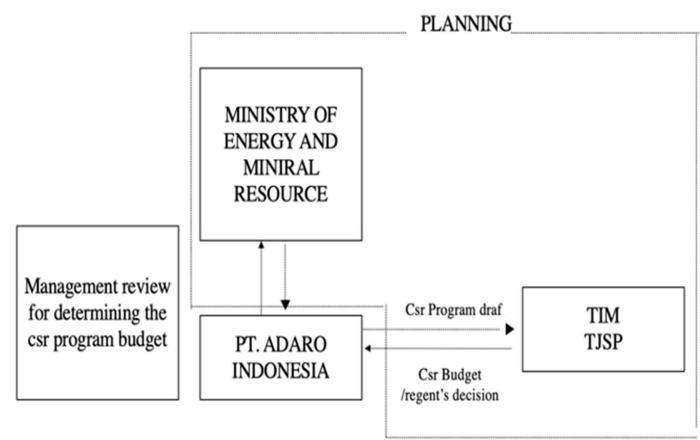

Figure 2. The mechanism for formulating PT Adaro Indonesia's CSR program.

The Corporate Social Responsibility Team, which is dominated by elements of the government apparatus, does not provide opportunities for the public or interest groups to participate optimally. The dominance of the corporate social responsibility team in planning and determining the program will also bring CSR into the politics of the authorities, even though it involves the district level government to the department in planning, the tumpeng tindah program will still occur because the corporate social responsibility team (TJSP) does not fully know about the situation in the village, this is related to the absence of sub-district, village, and community involvement in the planning phase, the determination of the program by the CSR team also has not used the approach to the potential and problems of the Balangan district community, the mechanism for program formulation has not used an investigation, mapping,

\subsection{Policy Implementation}

Government policies in the Corporate Social Responsibility (CSR) program are generally conceptually adequate, but in terms of implementation, the CSR budget provided by Adaro includes Economy, Education, Health, Social Culture, and the environment, program implementation has not been effective, program activities have not been fully tested by public, participatory, and the competence of policy makers for corporate social responsibility programs is still low, the corporate social responsibility team formed based on the decision of the regent of balangan does not understand the concept or vision of CSR itself.

\subsection{Policy Output}

PT Adaro Indonesia's CSR program has not yet fully provided benefits for the people of Balangan Regency, especially in the field of community empowerment, it is known that PT Adaro Indonesia only provides funds to ring 1 villages affected by mining operations.

\subsection{Policy Outcomes}

PT Adaro Indonesia's CSR outcomes in the infrastructure sector have been going well, but in the field of empowerment and community welfare, Balangan Regency has not fully provided a positive impact, the outcome of PT Adaro Indonesia's Corporate social responsibility program in the field of community empowerment has not been seen, due to the lack of community participation in discussions. The program has reached the level of program implementation, so that programs that empower the community have not had a positive impact on the people of Balangan Regency.

\subsection{Impact of the Corporate Social Responsibility Program for the People of Balangan Regency.}

\subsubsection{Economic Impact}

An overview of the Balangan economy can be seen in the following figure [5]".

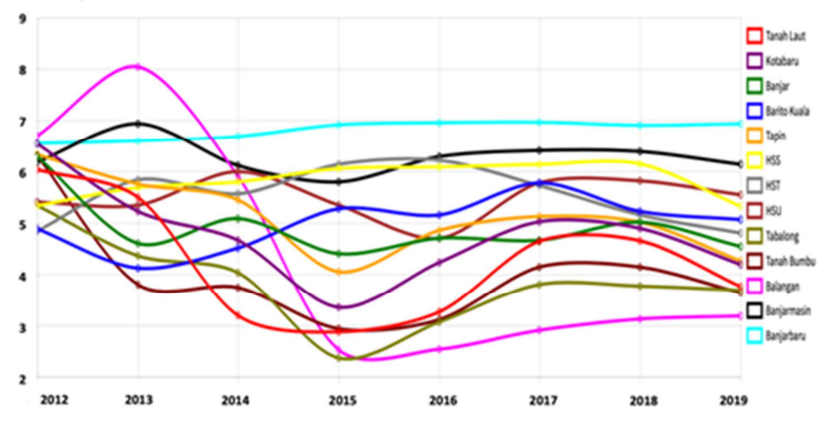

Figure 3. Economic growth in districts/cities in South Kalimantan 2020.

Based on the picture above, it is known that the economic growth of Balangan Regency is the lowest economic growth in South Kalimantan since 2016 - 2019. Observing the data, the government programs and PT Adaro Indonesia's CSR programs have not fully provided a positive impact on the economic growth of the people of Balangan Regency.

\subsubsection{Education Impact}

Based on bapsm-kalsel.or.id data, it is known that: School accreditation for SD/MI, SMP/MTs, and SMA/MA varies. At the SD level, 1 school gets a score of $65 \mathrm{D}$ accreditation is not accredited, a total of 16 schools get an accredited $\mathrm{C}$ score 9 schools get an accredited B grade and 1 elementary school gets an A accreditation if seen from the CSR budget of PT Adaro Indonesia for 2018-2020 in the education sector PT 
Adaro Indonesia's CSR assistance allocation of funds is more distributed to higher education scholarship assistance, not directly to the teaching aid process, therefore it can be concluded that PT Adaro's CSR program has not fully provided a positive impact on the process and outcomes of education in Balangan Regency.

\subsubsection{Health Impact}

PT Adaro Indonesia's CSR program in the field of Health includes assistance for providing clean water, KIBBLA, Healthy Schools, Health Social Services, Free Cataract Surgery and Health Support Infrastructure. Judging from several health programs implemented by PT Adaro Indonesia's CSR, the health sector has a positive impact on the life expectancy of the people of Balangan Regency. The following is the trend of the life expectancy of the people of Balangan Regency. [5]".

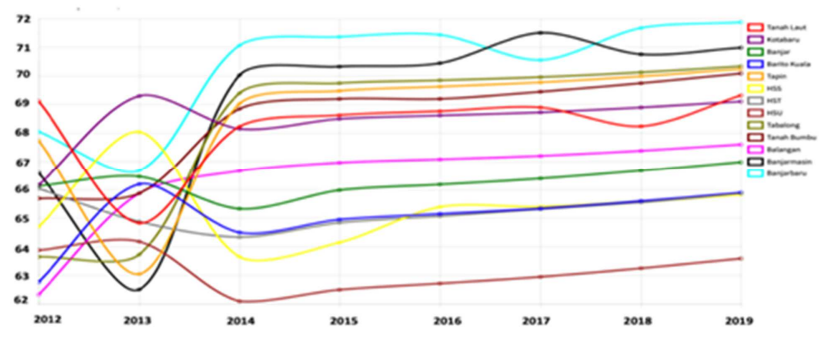

Figure 4. Regency/City life expectancy in South Kalimantan 2020.

\subsubsection{Socio-Cultural Impact}

PT Adaro Indonesia's program in the socio-cultural field is divided into two activities, first in the field of Arts and Culture Development and the second in sports development. In terms of impact, PT Adaro Indonesia's development plays a positive role in the development of Art, Culture and Sports facilities and infrastructure. However, in terms of empowering the positive impact it is still not fully optimal, especially for the Dayak pitap, it is known that the people of Balangan Regency consist of the Banjar tribe, called the Batang Balangan or pauk Balangan, and the Dayak tribe which is part of the Meratus Dayak tribe, (Dayak tap). Facilitation of activities for the Dayak tribe so far is still an annual event / activity, there are still few CSR programs for PT Adaro Indonesia to empower the Dayak pitap.

\subsubsection{Environmental Impact}

The environmental program aims to identify environmental potentials around the community, operational areas that can be used as efforts to improve environmental quality, PT Adaro Indonesia's CSR program in the environmental sector in the form of $3 \mathrm{R}$ waste management programs, environmental education and renewable energy, from several programs that have been implemented. running in the environmental field has not fully provided a positive impact, this is because the environmental program has not fully addressed the problems that arise due to mining activities, the negative impacts that arise in the community are noise, polluted water, damaged roads and the loss of flora and fauna in the mining area.

\section{Program Policy Evaluation Model}

Based on the results of research that has been carried out on the Evaluation of PT Adaro Indonesia's Corporate Social Responsibility (CSR) Program in empowering the people of Balangan Regency, South Kalimantan Province, the researchers propose a program policy evaluation model, as follows:

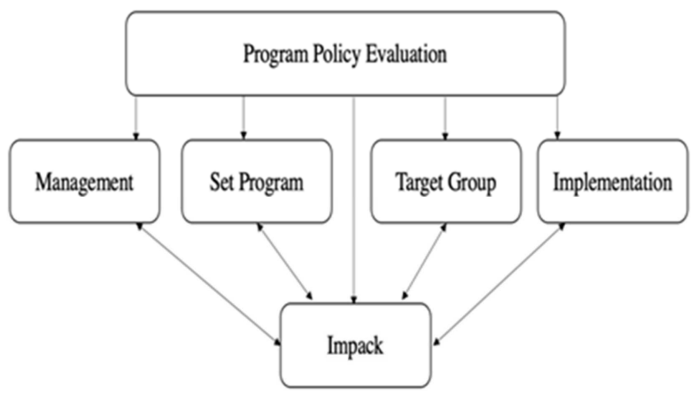

Figure 5. Program Policy Evaluation Model by Reno Affrian.

In the picture above, the program policy evaluation model can be explained as follows:

\subsection{Management}

Policy researchers can evaluate management, the evaluation materials are starting from program planning, materials used in the formulation of program policies, profiles of program policy makers, division of tasks and functions of program implementers, standard procedures (SOP) and coordination between interest groups.

\subsection{Defined Program}

Whether the program that has been determined is the needs of the target group, the evaluation material is why the program was held, whether the program is in accordance with the potential problems and in accordance with the needs of the supervisor.

\subsection{Target Group}

The target group is related to program beneficiaries, the evaluation materials are targeting accuracy, community participation.

\subsection{Implementation}

The implementation of program policies is to find out how far the programs that have been determined can be implemented, the evaluation materials are related to resources, communication, social politics, implementation strategies, and monitoring systems.

\subsection{Impact}

The impact of the program policy is an assessment of the program that has been implemented, whether the program has a positive or negative impact, the evaluation material is the benefit of the program, community satisfaction, the 
occurrence of changes for the wider community or parties who are subject to program policies.

\section{Conclusions and Suggestions}

Based on the results of the study, the conclusions in this study are as follows:

PT Adaro Indonesia realizes its social responsibility through several programs, namely 1 . Economy, 2. Education, 3. Health, 4. Socio-culture, and 4. Environment. The process of formulating and determining the CSR program of PT Adaro Indonesia is carried out by the Corporate Social Responsibility Work Team (TJSP) which was formed and determined through the Decree of the Regent of Balangan Regency. The composition of the CSR Team is clearly filled by local government officials based on echelon or structural positions without involving the level of the District, Village, NGOs, Independent Institutions, Academics and Communities Around the mine. society, so that the nature of CSR in the context of Community Empowerment is not yet optimal. On the other hand, government involvement that is too dominant in program planning and budgeting brings CSR into the political interests of entrepreneurs.

The role of PT Adaro Indonesia's CSR has not yet fully provided a positive impact for the people of Balangan Regency, Balangan Regency's economic growth is the lowest economic growth in the Regency/City in South Kalimantan since 2016 until now. Of course, the programs that have been set in the economic sector have not run effectively to increase economic growth in Balangan Regency. The education sector has also not had a positive impact, this can be seen from the quality ratings of schools, learning facilities and infrastructure that have not fully met the national education standards, CSR assistance in the education sector is more distributed in higher education scholarship assistance, very minimal in the teaching assistance process, so that the education program has not had a positive impact. Health,. seen from several health programs that are run in the health sector have a positive impact. Based on data released by the Central Statistics Agency of South Kalimantan Province, the life expectancy of the people of Balangan Regency has experienced a significant increase in each year. This means that PT Adaro Indonesia's CSR program has a positive role in the impact of public health in Balangan Regency. Socio-cultural programs have not fully provided a positive impact for the Dayak pitap, empowerment for the Dayak pitap is still an annual event/activity, there are still few programs that directly touch the Dayak pitap. The environmental field of several programs that have been carried out in the environmental field have not fully provided a positive impact, This is because the environmental program has not fully addressed the problems that arise due to mining activities, the negative impacts that arise in the community, noise, polluted water, damaged roads and the loss of flora and fauna in the mining area. The low positive impact factor in PT Adaro Indonesia's CSR program is related to poor planning by the Corporate Social Responsibility (CSR) TEAM The team in program formulation has not used an investigative study approach, mapping community needs, so that the established program is not fully relevant to the potential and problems of the community.

The implications resulting from this research are the program policy evaluation concept model, namely, 1 Management Management, 2 established programs, 3 target groups, 4. implementation and 5 impacts.

\section{Suggestion}

Based on the conclusions, the following research suggestions are:

1. The authorities need to redesign the management of the CSR program involving interest groups.

2. The Corporate Social Responsibility Team (TJSP) needs to emphasize the distribution of CSR fund allocations in community empowerment programsso that the program has a long-term impact.

3. Furthermore, interested parties in the future can evaluate using the program policy evaluation model approach that the researcher developed.

\section{References}

[1] Abdul Wahab, 2008, Introduction to Public Policy Analysis. Right to Publish at UMM Press.

[2] Agustino, Leo. 2017. Fundamentals of Public Policy. Bandung: Alphabeta.

[3] Balangan Regency in Figures 2021.

[4] Bank Indonesia (BI), 2019. South Kalimantan Economic Report.

[5] Data.kalselprov.go.id.

[6] Dunn, William N, 2003, Introduction to Public Policy Analysis, Yogyakarta, Gadjah Mada University Press.

[7] Frynas, Jedrzej George. 2009. Beyond Corporate Social Responsibility: Oil Multinationals and Social, Challenges. New York: Cambridge University Press.

[8] Islamy, Irfan Muh 2017. Public Policy, South Tangerang, Open University.

[9] Kotler, Philip and Nancy Lee. 2005. Corporate Social Responsibility: Doing the Most Good for Your Company and Your Cause, New Jersey: John Willey and Sons, Inc.

[10] Mardikanto Totok, Soebianto Soebianto Poerwoko. 2019. Community Empowerment in a public policy perspective. Bandung Alphabeta.

[11] Nugroho, Rian 2014. Public Policy (Fourth edition revised 2012) Jakarta PT Gramedia.

[12] Prastowo, Joko and Miftachul Huda. 2011. Corporate Social Responsibility Key to Achieve Business Glory. Yogyakarta: Blue Ocean.

[13] Satiri, Djam'an and Komariah, Aan, 2014. Methodology of Qualitative Research Bandung, Cv Alfabeta. 
[14] Sugiyono, 2017. Policy Research Methods. Alphabet.

[15] Sugiyono. (2017). Quantitative, Qualitative, and R\&D Research Methods. Bandung: Alfabeta, CV.

[16] Suharto, Edi, 2009. Social Work in the Industrial World, Strengthening CSR, Bandung: CV. Alphabet.
[17] Wibisono, Yusuf. 2007, Discussing the Concept \& Application of CSR (Corporate Social Responsibility), PT Gramedia, Jakarta.

[18] Winarno, Budi 2008. Public Policy, Pt. Our Book: Jakarta. 